Article

\title{
Characteristics and Mechanism of Vinyl Ether Cationic Polymerization in Aqueous Media Initiated by Alcohol/B $\left(\mathrm{C}_{6} \mathrm{~F}_{5}\right)_{3} / \mathrm{Et}_{2} \mathrm{O}$
}

\author{
Jinghan Zhang ${ }^{1,3}$, Yibo $\mathrm{Wu}^{2,3, * \mathbb{D}}$, Kaixuan Chen ${ }^{2}$, Min Zhang ${ }^{2,3}$, Liangfa Gong ${ }^{2}$, \\ Dan Yang ${ }^{2,3}\left(\mathbb{D}\right.$, Shuxin $\mathrm{Li}^{2,3}$ and Wenli Guo ${ }^{1,3, *}$ \\ 1 College of Material Science and Engineering, Beijing University of Chemical Technology, \\ Beijing 100029, China; zhanginghan0517@163.com \\ 2 Department of Materials Science and Engineering, Beijing Institute of Petrochemical Technology, \\ Beijing 102617, China; sunyongjun1120@163.com (K.C.); zm0127@nwpu.edu.cn (M.Z.); \\ gongliangfa@bipt.edu.cn (L.G.); yangdan@bipt.edu.cn (D.Y.); lishuxin@bipt.edu.cn (S.L.) \\ 3 Beijing Key Lab of Special Elastomeric Composite Materials, Beijing 102617, China \\ * Correspondence: wuyibo@bipt.edu.cn (Y.W.); gwenli@bjzx.gov.cn (W.G.)
}

Received: 28 February 2019; Accepted: 11 March 2019; Published: 14 March 2019

\begin{abstract}
Aqueous cationic polymerizations of vinyl ethers (isobutyl vinyl ether (IBVE), 2-chloroethyl vinyl ether (CEVE), and $n$-butyl vinyl ether $(n$-BVE)) were performed for the first time by a $\mathrm{CumOH} / \mathrm{B}\left(\mathrm{C}_{6} \mathrm{~F}_{5}\right)_{3} / \mathrm{Et}_{2} \mathrm{O}$ initiating system in an air atmosphere. The polymerization proceeded in a reproducible manner through the careful design of experimental conditions (adding initiator, co-solvents, and surfactant or decreasing the reaction temperature), and the polymerization characteristics were systematically tested and compared in the suspension and emulsion. The significant difference with traditional cationic polymerization is that the polymerization rate in aqueous media using $\mathrm{B}\left(\mathrm{C}_{6} \mathrm{~F}_{5}\right)_{3} / \mathrm{Et}_{2} \mathrm{O}$ as a co-initiator decreases when the temperature is lowered. The polymerization sites are located on the monomer/water surface. Density functional theory (DFT) was applied to investigate the competition between $\mathrm{H}_{2} \mathrm{O}$ and alcohol combined with $\mathrm{B}\left(\mathrm{C}_{6} \mathrm{~F}_{5}\right)_{3}$ for providing a theoretical basis. The effectiveness of the proposed mechanism for the aqueous cationic polymerization of vinyl ethers using $\mathrm{CumOH} / \mathrm{B}\left(\mathrm{C}_{6} \mathrm{~F}_{5}\right)_{3} / \mathrm{Et}_{2} \mathrm{O}$ was confirmed.
\end{abstract}

Keywords: aqueous cationic polymerization; suspension polymerization; emulsion polymerization; poly(vinyl ether); tris(pentafluorophenyl)borane; density functional theory

\section{Introduction}

Conventional cationic polymerizations of vinyl monomers, such as isobutylene (IB), vinyl ethers, and styrene, are usually achieved by using initiator/co-initiator systems primarily in chlorinated solvents under low-temperature and strict water-free conditions [1-8]. Chlorinated solvents seriously damage the environment, and their applications should be limited $[9,10]$. Under the advocacy of green chemistry, the use of environmentally benign solvents in cationic polymerization has been extensively studied, such as using fewer toxic solvents (e.g., toluene or $n$-hexane) [11-13], supercritical $\mathrm{CO}_{2}[14,15]$, and ionic liquids [16-20]. Water is one of the most ideal polymerization solvents. However, traditional co-initiators are water-sensitive and decompose when excessive quantities of water are present [21,22]. Because $\mathrm{Yb}(\mathrm{OTf})_{3}$ was first investigated as a water-tolerant co-initiator for its ability to induce the polymerization of $p$-methoxystyrene (pMOS) in 1999 [23], considerable attention has been paid to the utilization of aqueous cationic polymerization. With the development of various water-tolerant Lewis acids (LAs), this new polymer synthesis technology has achieved remarkable breakthroughs [21]. 
Early studies on aqueous cationic polymerizations of reactive monomer $p$-methoxystyrene using 1-chloro-1-(p-methoxyphenyl)ethane (pMOS- $\mathrm{HCl})$ combined with lanthanide triflates as an initiator/co-initiator system shared two main features: (a) the polymerization sites were located on the monomer/water surface; (b) the molecular weights of the polymers obtained in aqueous media were relatively low due to the "critical degree of polymerization" effect [23-25]. The next generation of catalysts, called "Lewis acid surfactant combined catalysts" (LASC), that is, a triflic acid in conjunction with a non-ionic surfactant, can transfer the polymerization site from the monomer/water surface to the interior of the monomer, resulting in the production of long polymer chains [26-29]. However, these LASCs still lack activity, and the polymerizations proceed at high temperatures (from $40{ }^{\circ} \mathrm{C}$ to $60{ }^{\circ} \mathrm{C}$ ). Recently, potential initiating systems based on boranes were introduced for the aqueous cationic polymerization of industrially important monomers. $\mathrm{BF}_{3} \mathrm{OEt}_{2}$ induces the styrene cationic polymerizations when a small amount of water is present [30,31]. However, excessive quantities of water would easily deactivate this co-initiator in styrene polymerization [30]. $\mathrm{B}\left(\mathrm{C}_{6} \mathrm{~F}_{5}\right)_{3}$, which does not decompose in an air atmosphere or in water, successfully promotes the aqueous cationic polymerization of styrene and its derivatives [32,33], cyclopentadiene [33,34] and isoprene [35], but this material is inactive for polymerizing IB [36] and isobutyl vinyl ether (IBVE) [37] in aqueous media. The noncommercial chelating diborane $\left(\mathrm{o}^{-} \mathrm{C}_{6} \mathrm{~F}_{4}\left[\mathrm{~B}\left(\mathrm{C}_{6} \mathrm{~F}_{5}\right)_{2}\right]_{2}\right)$ [38] and diborole $\left(\mathrm{o}-\mathrm{C}_{6} \mathrm{~F}_{4}\left[9-\mathrm{BC}_{12} \mathrm{~F}_{8}\right]_{2}\right)[38,39]$ ionize various cumyl derivatives and play the role of co-initiators in the aqueous cationic polymerization of IB. (Pentafluorophenyl)group 13 metal compounds $\mathrm{Al}\left(\mathrm{C}_{6} \mathrm{~F}_{5}\right)_{3}$ and $\mathrm{Ga}\left(\mathrm{C}_{6} \mathrm{~F}_{5}\right)_{3}[36]$, which are structurally similar to $\mathrm{B}\left(\mathrm{C}_{6} \mathrm{~F}_{5}\right)_{3}$ but unstable in an air atmosphere, were recently tested for the aqueous cationic polymerization of IB under harsh experimental conditions (in $\mathrm{LiCl} / \mathrm{NaCl} / \mathrm{H}_{2} \mathrm{O}$ diluents under $\mathrm{N}_{2}$ atmosphere at $-60^{\circ} \mathrm{C}$ ).

To date, only IBVE has been reported for cationic polymerization of vinyl ethers in aqueous media, and there have been no reports on the aqueous cationic polymerization of 2-chloroethyl vinyl ether (CEVE) and $n$-butyl vinyl ether ( $n$-BVE). To the best of our knowledge, only two types of co-initiators, namely, $\mathrm{BF}_{3} \mathrm{OEt}_{2}$ and $\mathrm{H}_{3} \mathrm{PW}_{12} \mathrm{O}_{40}$ and its salts have been reported for cationic polymerization of IBVE in aqueous media [22,37]. $\mathrm{BF}_{3} \mathrm{OEt}_{2}$ induces polymerization in a highly exothermic manner, and $\mathrm{H}_{3} \mathrm{PW}_{12} \mathrm{O}_{40}$ and its salts induce polymerization in an $\mathrm{N}_{2}$ atmosphere with a previous preparation of IBVE- $\mathrm{HCl}$ adduct to provide low-molecular-weight poly(IBVE)s $\left(1200-4500 \mathrm{~g} \mathrm{~mol}^{-1}\right)$. It is generally believed that $\mathrm{B}\left(\mathrm{C}_{6} \mathrm{~F}_{5}\right)_{3}$, which is used to initiate the aqueous cationic polymerization of styrene, cannot initiate the aqueous cationic polymerization of IBVE [37]. However, we believe that $\mathrm{B}\left(\mathrm{C}_{6} \mathrm{~F}_{5}\right)_{3}$, which has high activity, will promote the aqueous cationic polymerization of more active monomer vinyl ethers. In this study, we synthesized poly(IBVE)s, poly(CEVE), and poly(n-BVE) in aqueous suspensions and emulsions by using $\mathrm{B}\left(\mathrm{C}_{6} \mathrm{~F}_{5}\right)_{3} / \mathrm{Et}_{2} \mathrm{O}$ complexes under an air atmosphere in the range of $-10^{\circ} \mathrm{C}$ to $20^{\circ} \mathrm{C}$. Severely exothermic reactions and poor polymerization reproducibility were overcome by identifying an appropriate initiator, diluents, and surfactants. We observed that the polymerization rate decreased when the temperature was reduced. The polymerization sites were located on the monomer/water surface. The possible mechanism of vinyl ether cationic polymerization in aqueous media was systematically studied by density functional theory (DFT), kinetics, and end group analysis.

\section{Materials and Methods}

\subsection{Materials}

Methanol (Beijing Chemical Works, Beijing, China, 99.9\%), ethanol (EtOH, Beijing Chemical Works, 99.7\%), cumyl alcohol (CumOH, Beijing Chemical Works, 97\%), diethyl ether (Beijing Chemical Works, 99.5\%), isopropanol (IPA, Beijing Chemical Works, 99.5\%), $\mathrm{B}\left(\mathrm{C}_{6} \mathrm{~F}_{5}\right)_{3}$ (J\&K Scientific Ltd., Beijing, China, 97\%), hexadecyltrimethylammonium bromide (CTAB, J\&K Scientific Ltd., 99\%), toluene (Beijing Chemical Works, 99.5\%), 4-nonylphenyl-polyethylene glycol (NP-40, J\&K Scientific Ltd.), $\mathrm{NaCl}$ (Beijing Chemical Works, 99\%), sodium dodecylbenzenesulfonate (SDBS, J\&K Scientific Ltd., 95\%), deuterated chloroform ( $\mathrm{CDCl}_{3}$, J\&K Scientific Ltd., 99.8\%), $n$-hexane (Beijing Chemical Works, 
99.5\%), and tetrahydrofuran (THF) (J\&K Scientific Ltd., 99.9\%) were used as received. IBVE (J\&K Scientific Ltd., 99.0\%), 2-chloroethyl vinyl ether (J\&K Scientific Ltd., 97.0\%), and $n$-butyl vinyl ether (J\&K Scientific Ltd., 98.0\%) were distilled in a nitrogen atmosphere before use.

\subsection{States of Suspension and Emulsion}

Aqueous suspension and emulsion systems were investigated in this study. For the suspension, high-purity water, $\mathrm{NaCl}$ solution, and a mixture of water and toluene or $n$-hexane were used as polymerization media. Monomer droplets were visible to the naked eye at $150 \mathrm{rpm}$ (mechanical stirring). Organic and water phases were separated rapidly after stopping the mechanical stirrer. For the emulsion, CTAB, NP-40, and SDBS were applied to the media. Phase separation was observed at $0.5 \mathrm{~h}$ after stopping the mechanical stirrer $(150 \mathrm{rpm})$. The average particle size ranged from 51 to $59 \mathrm{~nm}$, and the standard deviation ranged from 17 to $20 \mathrm{~nm} . \mathrm{B}\left(\mathrm{C}_{6} \mathrm{~F}_{5}\right)_{3}$ did not dissolve when it was added to the high-purity water. After adding a small amount of diethyl ether, $\mathrm{B}\left(\mathrm{C}_{6} \mathrm{~F}_{5}\right)_{3}$ dissolved and formed a milky solution.

\subsection{Polymerizations}

\subsubsection{Vinyl Ether Cationic Polymerization in Suspension}

The polymerizations were implemented in an air atmosphere in the range between $-10{ }^{\circ} \mathrm{C}$ and $20^{\circ} \mathrm{C}$ in glass culture tubes $(60 \mathrm{~mL}) . \mathrm{H}_{2} \mathrm{O}(3 \mathrm{~mL})$, the monomer $(1 \mathrm{~mL})$, and an initiator (EtOH, IPA, or $\mathrm{CumOH}$ ) were added to a reactor, which was then warmed to a predetermined polymerization temperature for $20 \mathrm{~min}$ by immersion in an ethanol/water $(50 / 50)$ bath. In several cases, $\mathrm{NaCl}$, $n$-hexane, and toluene were added to the recipe. Then, $\mathrm{B}\left(\mathrm{C}_{6} \mathrm{~F}_{5}\right)_{3}\left(0.128 \mathrm{~g}, 2.5 \times 10^{-4} \mathrm{~mol}\right), \mathrm{H}_{2} \mathrm{O}(2 \mathrm{~mL})$, and diethyl ether $\left(5 \times 10^{-4} \mathrm{~mol}\right)$ were mixed in a beaker in order and warmed to a predetermined polymerization temperature for a sufficient amount of time. Then, the mixture in the beaker was poured into the reactor under mechanical stirring at $150 \mathrm{rpm}$. The temperature probe (Testo 176T4) was located below the liquid level. After a predetermined time, the suspension media was poured out into excess methanol. The polymers were washed three times with methanol and dried in a vacuum oven at $30^{\circ} \mathrm{C}$.

\subsubsection{Vinyl Ether Cationic Polymerization in Emulsion}

The polymerizations were implemented under the condition of adding an emulsifier. $\mathrm{H}_{2} \mathrm{O}$ (3 mL), a surfactant (NP-40, CTAB, or SDBS), monomer $(1 \mathrm{~mL})$, and CumOH $\left(0.034 \mathrm{~g}, 2.5 \times 10^{-4} \mathrm{~mol}\right)$ were added to a reactor with mechanical stirring at $150 \mathrm{rpm}$. The reactor was then warmed to a predetermined polymerization temperature for $20 \mathrm{~min}$ by immersion in an ethanol/water (50/50) bath. $\mathrm{B}\left(\mathrm{C}_{6} \mathrm{~F}_{5}\right)_{3}\left(0.128 \mathrm{~g}, 2.5 \times 10^{-4} \mathrm{~mol}\right), \mathrm{H}_{2} \mathrm{O}(2 \mathrm{~mL}, 0.13 \mathrm{M})$, and diethyl ether $\left(5 \times 10^{-4} \mathrm{~mol}\right)$ were mixed in a beaker in order and warmed to a predetermined polymerization temperature for a sufficient amount of time. The mixture in the beaker was poured afterward into the reactor. Subsequent processing was similar to that for polymerization in an aqueous suspension.

\subsection{Measurements}

Proton nuclear magnetic resonance $\left({ }^{1} \mathrm{H}-\mathrm{NMR}\right)$ spectra of the poly(vinyl ether)s were recorded in $\mathrm{CDCl}_{3}$ as solvents at $25^{\circ} \mathrm{C}$ on a Bruker-500 MHz spectrometer calibrated with tetramethylsilane as the internal standard $\left(\delta_{\mathrm{H}}=0.00\right)$. Molecular weights and $M W D\left(M_{\mathrm{W}} / M_{\mathrm{n}}\right)$ of the poly(vinyl ether)s were obtained from a gel permeation chromatography (GPC) system with universal calibration using a Waters e2695 separations module, a Waters 2489 UV detector, a Waters 2414 RI detector, and four Waters styragel columns connected in the following order: $500,10^{3}, 10^{4}$, and $10^{5}$. THF served as a solvent for the polymers with a concentration of $20 \mathrm{mg}$ of polymer $/ 10 \mathrm{~mL}$ of THF and mobile phase at a flow rate of $1.0 \mathrm{~mL} / \mathrm{min}$. ATR-FTIR spectra were recorded in situ by using a Mettler Toledo ReactIR 15 instrument with a DiComp probe coupled with an Material HgCdTe detector via AgX 
fiber. Sampling wavenumbers were from 4000 to $600 \mathrm{~cm}^{-1}$ at a resolution of $2 \mathrm{~cm}^{-1}$. The particle size in the emulsion was tested by a dynamic light scattering (DLS) analysis system using a Nanosight LM20. The reaction system temperature was detected with Testo 176T4, a data logger that records temperature per second.

\subsection{Computational Method}

All the calculations were performed with Gaussian 03 software (Version 6.0, Gaussian Inc., Wallingford, CT, USA). Geometry optimizations and vibrational frequency calculations were carried out via the density functional theory (DFT) BP86: Becke's 1988 exchange functional [40] with Perdew's correlation functional [41] using 6-31G* basis sets for C, H, O, B, F. This gave the charges of carbocation and the atoms' distances.

\section{Results and Discussion}

\subsection{Testing of Different Initiators}

The reaction between $\mathrm{B}\left(\mathrm{C}_{6} \mathrm{~F}_{5}\right)_{3}$ and $\mathrm{Et}_{2} \mathrm{O}$ were investigated with ATR-FTIR spectroscopy, as

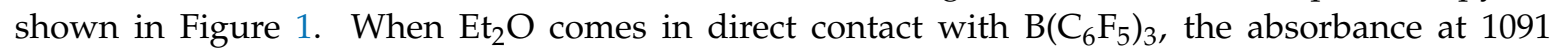
and $774 \mathrm{~cm}^{-1}$ is changed, which indicates the interaction between $\mathrm{B}\left(\mathrm{C}_{6} \mathrm{~F}_{5}\right)_{3}$ and $\mathrm{Et}_{2} \mathrm{O}$ [42-44]. The $\mathrm{B}\left(\mathrm{C}_{6} \mathrm{~F}_{5}\right)_{3} / \mathrm{Et}_{2} \mathrm{O}$ complex can react with $\mathrm{H}_{2} \mathrm{O}$ or alcohols to form an active species, which can initiate polymerization (Table 1). Given that IBVE is one of the most reactive monomers in conventional cationic polymerization [16,37], $\mathrm{H}_{2} \mathrm{O}$ as an initiator combined with the co-initiator $\mathrm{B}\left(\mathrm{C}_{6} \mathrm{~F}_{5}\right)_{3}$ induced rapid cationic polymerization of IBVE in the aqueous suspension in a highly exothermic (even explosive) and non-reproducible manner at $20^{\circ} \mathrm{C}$ (run 1 in Table 1). To achieve an efficient and stable polymerization process, we used primary, secondary, and tertiary alcohols as initiators in this study. The maximum temperatures during polymerizations initiated by $\mathrm{H}_{2} \mathrm{O}, \mathrm{EtOH}$, IPA, and $\mathrm{CumOH} / \mathrm{B}\left(\mathrm{C}_{6} \mathrm{~F}_{5}\right)_{3} / \mathrm{Et}_{2} \mathrm{O}$ were typically above the boiling point of IBVE $\left(83^{\circ} \mathrm{C}\right.$ ) (Figure 2). Only CumOH/B $\left(\mathrm{C}_{6} \mathrm{~F}_{5}\right)_{3}$ did not induce the polymerization in an explosive and non-reproducible manner (Table 1). The longest preparation time $(18 \mathrm{~s})$ and lowest maximum temperature $\left(98.6^{\circ} \mathrm{C}\right)$ during polymerization initiated by $\mathrm{CumOH} / \mathrm{B}\left(\mathrm{C}_{6} \mathrm{~F}_{5}\right)_{3}$ indicated that using the $\mathrm{CumOH} / \mathrm{B}\left(\mathrm{C}_{6} \mathrm{~F}_{5}\right)_{3}$ initiating system was the most stable approach. $\mathrm{CumOH}$ had high initiating activity in aqueous media, as proven by the polymerization rates of styrene in the aqueous suspension initiated by $\mathrm{H}_{2} \mathrm{O}, \mathrm{EtOH}, \mathrm{IPA}$, and $\left.\mathrm{CumOH} / \mathrm{B}_{(} \mathrm{C}_{6} \mathrm{~F}_{5}\right)_{3}$ (Figure S1). Because $\mathrm{B}\left(\mathrm{C}_{6} \mathrm{~F}_{5}\right)_{3}$ is dissolved in water before it is placed into the reactor, competitive complexing should occur between $\mathrm{H}_{2} \mathrm{O} / \mathrm{B}\left(\mathrm{C}_{6} \mathrm{~F}_{5}\right)_{3}$ and $\mathrm{CumOH} / \mathrm{B}\left(\mathrm{C}_{6} \mathrm{~F}_{5}\right)_{3}$ initiating systems. DFT was used to study the interactions between the initiator and co-initiator (see Section 3.5 for details). The polymers obtained from the $\mathrm{CumOH} / \mathrm{B}\left(\mathrm{C}_{6} \mathrm{~F}_{5}\right)_{3}$ initiating system exhibited generally narrower MWDs than did those obtained from other systems (Table 1).

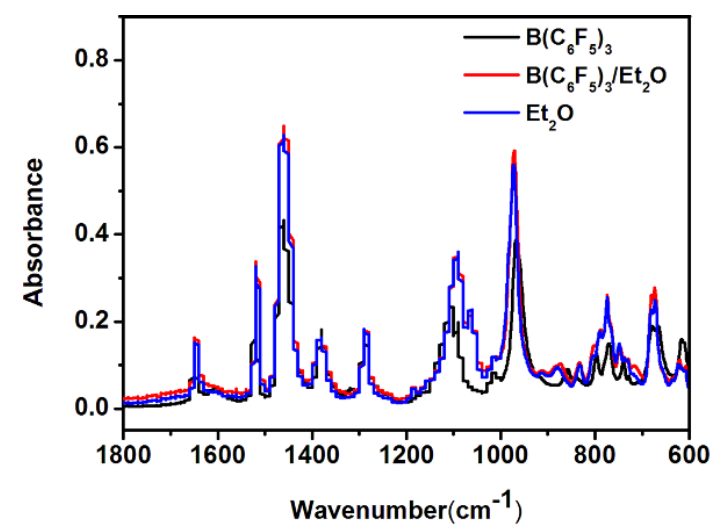

Figure 1. ATR-FTIR spectra for the interaction between $\mathrm{B}\left(\mathrm{C}_{6} \mathrm{~F}_{5}\right)_{3}$ and $\mathrm{Et}_{2} \mathrm{O}$ at $20{ }^{\circ} \mathrm{C}$. $\left[\mathrm{B}\left(\mathrm{C}_{6} \mathrm{~F}_{5}\right)_{3}\right]=0.05 \mathrm{M}$; $\left[\mathrm{Et}_{2} \mathrm{O}\right]=0.1 \mathrm{M}$. 
Table 1. Suspension cationic polymerization of isobutyl vinyl ether (IBVE) in the presence of different initiators ${ }^{\text {a. }}$

\begin{tabular}{ccccc}
\hline run & Initiator (content) (mmol) & Conv. $^{\mathbf{b}}( \pm \mathbf{S})(\mathbf{\%})$ & $\boldsymbol{M}_{\boldsymbol{n}}{ }^{\boldsymbol{c}}(\mathrm{GPC})\left(\mathbf{g ~ m o l}^{-\mathbf{1}}\right)$ & $\boldsymbol{M}_{\boldsymbol{w}} / \boldsymbol{M}_{\boldsymbol{n}}{ }^{\mathbf{c}}$ \\
\hline 1 & $\mathrm{H}_{2} \mathrm{O}(\infty)$ & $30.1( \pm 15.4)$ & 4690 & 1.88 \\
2 & $\mathrm{EtOH}(0.25)$ & $45.2( \pm 15.6)$ & 4310 & 2.01 \\
3 & $\mathrm{IPA}(0.25)$ & $43.3( \pm 7.7)$ & 5940 & 1.57 \\
4 & $\mathrm{CumOH}(0.25)$ & $48.3( \pm 1.6)$ & 6270 & 1.39 \\
\hline
\end{tabular}

a Polymerization conditions: $\mathrm{H}_{2} \mathrm{O}$ (total): $5 \mathrm{~mL} ; \mathrm{IBVE}: 1 \mathrm{~mL} ; \mathrm{B}_{(}\left(\mathrm{C}_{6} \mathrm{~F}_{5}\right)_{3}: 0.25 \mathrm{mmol} ; \mathrm{T}=20^{\circ} \mathrm{C}$; mechanically stirring at $150 \mathrm{rpm} .{ }^{\mathrm{b}}$ Conversion value came from the average of 5 experimental runs with each initiator along with the respective standard deviation. ${ }^{c} M_{n}$ and $M_{w} / M_{n}$ value came from the polymer of which conversion was closest to the averages of each group.

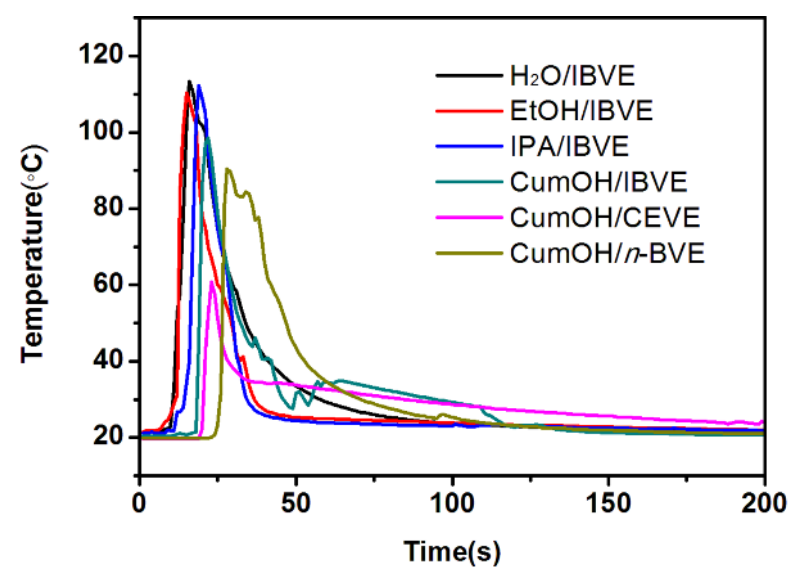

Figure 2. Temperature during cationic polymerizations of vinyl ethers initiated by different alcohols $/ \mathrm{B}\left(\mathrm{C}_{6} \mathrm{~F}_{5}\right)_{3} / \mathrm{Et}_{2} \mathrm{O}$ in aqueous suspensions at $20{ }^{\circ} \mathrm{C}$ : $[\mathrm{IBVE}]=1.6 \mathrm{M}$; [CEVE] $=2.0 \mathrm{M}$; $[n-\mathrm{BVE}]=1.6 \mathrm{M} ;[\mathrm{EtOH}]=[\mathrm{IPA}]=[\mathrm{CumOH}]=0.05 \mathrm{M} ;\left[\mathrm{B}\left(\mathrm{C}_{6} \mathrm{~F}_{5}\right)_{3}\right]=0.05 \mathrm{M} ;\left[\mathrm{Et}_{2} \mathrm{O}\right]=0.1 \mathrm{M}$. CEVE: 2-chloroethyl vinyl ether; $n$-BVE: $n$-butyl vinyl ether; IPA: isopropanol.

\subsection{Polymerization in Aqueous Suspension}

\subsubsection{Effect of Initiator Concentration}

The aqueous cationic polymerization of IBVE was conducted in $\mathrm{H}_{2} \mathrm{O}$ using $\mathrm{B}\left(\mathrm{C}_{6} \mathrm{~F}_{5}\right)_{3}$ combined with different concentrations of $\mathrm{CumOH}$ at $20{ }^{\circ} \mathrm{C}$ (Figure 3). Because $\left.\mathrm{B}_{(} \mathrm{C}_{6} \mathrm{~F}_{5}\right)_{3}$ was dissolved in water, the polymerization sites in $\mathrm{H}_{2} \mathrm{O}$ were on the monomer/water surface. Figure 3 indicates that the IBVE polymerization rate increased slightly with increases in the concentration of $\mathrm{CumOH}$. The highest monomer conversion was only $52 \%$ at $[\mathrm{CumOH}]=0.15 \mathrm{M}$ (Figure $3 \mathrm{a}$ ), which may be due to the chain-transfer reaction during polymerization. By contrast, the number average molecular weight $\left(M_{n}\right)$ decreased as the concentration of $\mathrm{CumOH}$ increased (Figure 3b). The increase of $M_{n}$ with monomer conversion at the later stage of polymerization was due to a coupling reaction during the later stages of the polymerization (see Section 3.6 for details). The polymers obtained in $\mathrm{H}_{2} \mathrm{O}$ exhibited broad MWDs, indicating that the suspension polymerization was not controlled. The nonlinear curves of $\ln \left(\left[M_{0}\right] /[M]\right)$ versus time (Figure 3c) illustrated that the number of active species in aqueous suspension processes decreased continuously with time.

\subsubsection{Effect of Diluents}

Given that the polymerization sites in $\mathrm{H}_{2} \mathrm{O}$ were on the monomer/water surface, we assumed that the use of an organic, hardly water-soluble cosolvent or $\mathrm{NaCl}$ solution would dilute the monomer and decrease the reaction exotherm. In the presence of $n$-hexane, toluene, or $\mathrm{NaCl}$, polymerization in the aqueous suspension proceeded in a reasonable, reproducible manner from $-10{ }^{\circ} \mathrm{C}$ to $20^{\circ} \mathrm{C}$. The reaction exotherms decreased, and the preparation times during polymerizations increased in 
these cases (Figure 4). The use of these diluents ( $n$-hexane $/ \mathrm{H}_{2} \mathrm{O}$, toluene $/ \mathrm{H}_{2} \mathrm{O}$, or $\mathrm{NaCl}$ solution) led to a decline in monomer conversion and $M_{n}$, except for the polymerization in $\mathrm{H}_{2} \mathrm{O}$ at $+0{ }^{\circ} \mathrm{C}$ (Table 2).
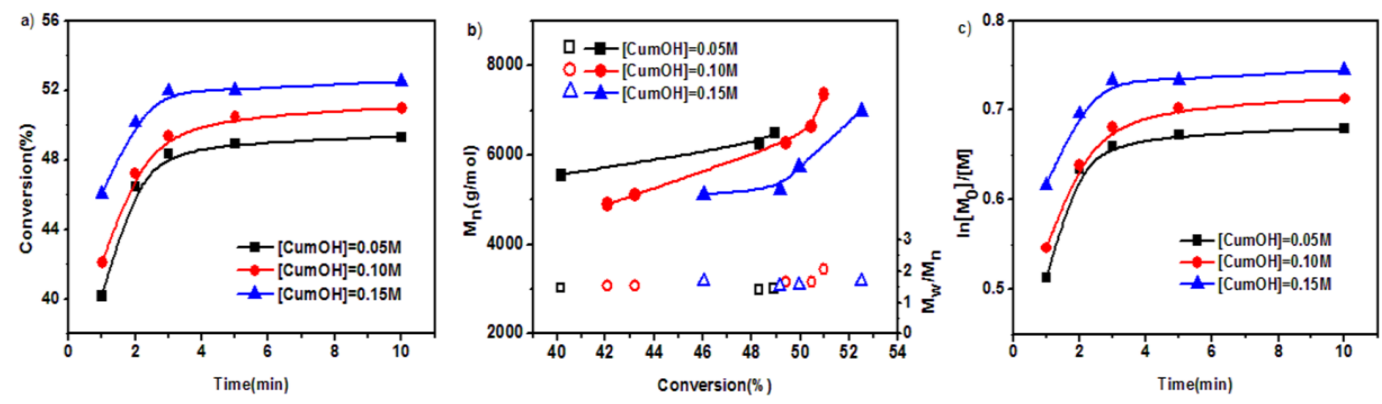

Figure 3. IBVE cationic polymerization initiated by $\mathrm{CumOH} / \mathrm{B}\left(\mathrm{C}_{6} \mathrm{~F}_{5}\right)_{3} / \mathrm{Et}_{2} \mathrm{O}$ in $\mathrm{H}_{2} \mathrm{O}$ at $20{ }^{\circ} \mathrm{C}$ : (a) conversion vs time; (b) $M_{n}$ and $M_{w} / M_{n}$ vs conversion; (c) $\ln \left[M_{0}\right] /[M]$ vs time. [IBVE] $=1.6 \mathrm{M}$; $\left[\mathrm{B}\left(\mathrm{C}_{6} \mathrm{~F}_{5}\right)_{3}\right]=0.05 \mathrm{M} ;\left[\mathrm{Et}_{2} \mathrm{O}\right]=0.1 \mathrm{M}$.

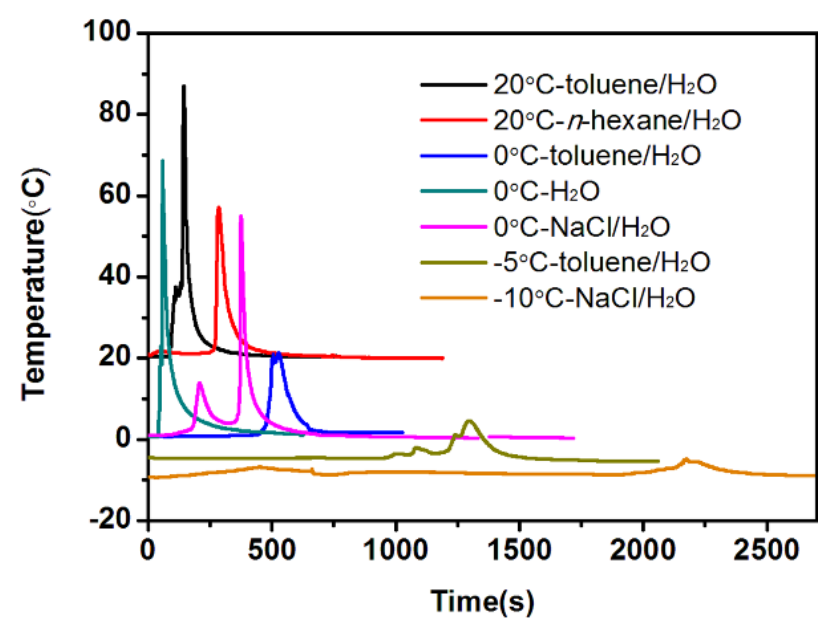

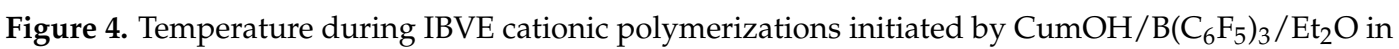
an aqueous suspension: toluene: $1 \mathrm{~mL} ; \mathrm{NaCl}: 1 \mathrm{~g} ;[\mathrm{IBVE}]=1.6 \mathrm{M} ;[\mathrm{CumOH}]=\left[\mathrm{B}\left(\mathrm{C}_{6} \mathrm{~F}_{5}\right)_{3}\right]=0.05 \mathrm{M}$; $\left[\mathrm{Et}_{2} \mathrm{O}\right]=0.1 \mathrm{M}$.

Table 2. Suspension cationic polymerization of IBVE at different temperatures ${ }^{\mathrm{a}}$.

\begin{tabular}{|c|c|c|c|c|c|c|}
\hline Run & Medium & $\mathrm{T}\left({ }^{\circ} \mathrm{C}\right)$ & Time (min) & Conv. (\%) & $M_{n}(\mathrm{GPC})\left(\mathrm{g} \mathrm{mol}^{-1}\right)$ & $M_{w} / M_{n}$ \\
\hline 5 & $\mathrm{H}_{2} \mathrm{O}$ & 20 & 5 & 48.9 & 6500 & 1.39 \\
\hline 6 & $\mathrm{H}_{2} \mathrm{O}$ & 0 & 10 & 27.4 & 5020 & 1.41 \\
\hline 7 & $n$-hexane $/ \mathrm{H}_{2} \mathrm{O}$ & 20 & 17 & 44.2 & 4810 & 1.32 \\
\hline 8 & $n$-hexane $/ \mathrm{H}_{2} \mathrm{O}$ & 0 & 21 & 40.7 & 4690 & 1.28 \\
\hline 9 & $n$-hexane $/ \mathrm{H}_{2} \mathrm{O}$ & -5 & 27 & 24.7 & 4410 & 1.36 \\
\hline 10 & Toluene $/ \mathrm{H}_{2} \mathrm{O}$ & 20 & 17 & 42.6 & 4610 & 1.37 \\
\hline 11 & Toluene $/ \mathrm{H}_{2} \mathrm{O}$ & 0 & 21 & 35.1 & 4550 & 1.40 \\
\hline 12 & Toluene $/ \mathrm{H}_{2} \mathrm{O}$ & -5 & 27 & 22.7 & 4090 & 1.32 \\
\hline 13 & $\mathrm{NaCl}$ solution ${ }^{\mathrm{b}}$ & 20 & 15 & 37.3 & 4800 & 1.36 \\
\hline 14 & $\mathrm{NaCl}$ solution ${ }^{\mathrm{b}}$ & 0 & 27 & 28.7 & 3040 & 1.42 \\
\hline 15 & $\mathrm{NaCl}$ solution ${ }^{\mathrm{b}}$ & -10 & 47 & 23.0 & 2120 & 1.31 \\
\hline
\end{tabular}

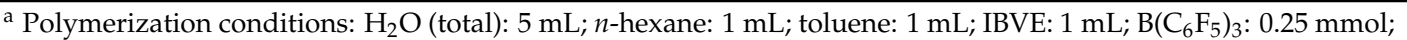
CumOH: $0.25 \mathrm{mmol}$; mechanically stirring at $150 \mathrm{rpm} .{ }^{\mathrm{b}} \mathrm{NaCl}: 1 \mathrm{~g}$.

These observations are consistent with the characteristics of interfacial reactions of IBVE polymerizations in aqueous media [37]. The use of co-solvents makes it difficult for $\mathrm{B}\left(\mathrm{C}_{6} \mathrm{~F}_{5}\right)_{3}$, which is dissolved in water, to reach the monomer, leading to a low monomer conversion and $M_{n}$. In the $\mathrm{NaCl}$ solution, the $\mathrm{Cl}^{-}$inhibits the positive charge of the active species [16,17], which results in a decrease in the polymerization rate on the monomer/water surface [45]. The yield and molecular weight of 
the polymerization in $\mathrm{H}_{2} \mathrm{O}$ at $+0^{\circ} \mathrm{C}$ (run 6 in Table 2) were lower than those of the polymerizations in other diluents probably because the high-purity water system was extremely near the freezing point.

\subsubsection{Effect of Temperature}

To increase the monomer conversion and $M_{n}$, the reaction temperature of IBVE polymerization in the aqueous suspension was reduced from $20^{\circ} \mathrm{C}$ to $-10^{\circ} \mathrm{C}$ (Table 2). When the reaction temperature was reduced, the reaction exotherms decreased, and the preparation times increased in all suspension processes. Meanwhile, a trend contrary to traditional cationic polymerizations [1-3,46] was observed. The yields and $M_{n}$ obtained in the aqueous suspension processes decreased when the reaction temperature was lowered. The possible reason for these observations might be the loss of the co-initiator activity when reaction temperature decreases. We also examined styrene polymerization in the aqueous suspension (Figure S2), and the characteristics were fully consistent with those in IBVE polymerization in the aqueous suspension. The loss of initiating activity with decreasing temperature might be the real reason $\mathrm{B}\left(\mathrm{C}_{6} \mathrm{~F}_{5}\right)_{3}$ could not induce $\mathrm{IB}$ cationic polymerization below $-20^{\circ} \mathrm{C}$.

\subsubsection{Other Vinyl Ethers}

To further understand the vinyl ether polymerization characteristics in suspension, CEVE and $n$-BVE were used as monomers to conduct polymerization. The cationic polymerizations of CEVE and $n$-BVE initiated by $\mathrm{CumOH} / \mathrm{B}\left(\mathrm{C}_{6} \mathrm{~F}_{5}\right)_{3} / \mathrm{Et}_{2} \mathrm{O}$ in aqueous suspensions proceeded in a reproducible manner. The incomplete monomer conversions ( $<75 \%)$ for IBVE (49.32\%), CEVE $(71.68 \%)$, and n-BVE $(58.40 \%)$ (Figures $3 \mathrm{a}$ and 5$)$ cationic polymerizations were observed due to the competition between the propagated consumption of the protonated monomer and the formation of acetaldehyde and other organic compounds, which were analyzed through ${ }^{1} \mathrm{H}-\mathrm{NMR}$ spectroscopy. [LZ2] The increase of $M_{n}$ with monomer conversion at the later stage of polymerization was also observed in CEVE and $n$-BVE cationic polymerizations.
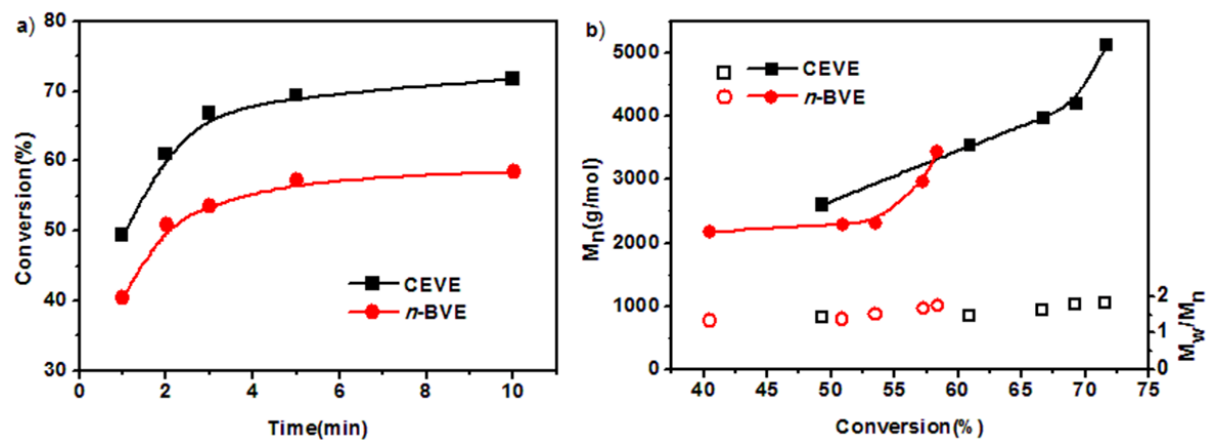

Figure 5. Cationic polymerization of CEVE and $n$-BVE initiated by $\mathrm{CumOH} / \mathrm{B}\left(\mathrm{C}_{6} \mathrm{~F}_{5}\right)_{3} / \mathrm{Et}_{2} \mathrm{O}$ in $\mathrm{H}_{2} \mathrm{O}$ at $20{ }^{\circ} \mathrm{C}$ : (a) conversion vs time; (b) $\mathrm{Mn}$ and $\mathrm{Mw} / \mathrm{Mn}$ vs conversion; $[\mathrm{CEVE}]=2.0 \mathrm{M} ;[n-\mathrm{BVE}]=1.6 \mathrm{M}$; $[\mathrm{CumOH}]=\left[\mathrm{B}\left(\mathrm{C}_{6} \mathrm{~F}_{5}\right)_{3}\right]=0.05 \mathrm{M} ;\left[\mathrm{Et}_{2} \mathrm{O}\right]=0.1 \mathrm{M}$.

\subsection{Polymerization in Aqueous Emulsions}

To better understand the influence of the aqueous environment on vinyl ether cationic polymerization, poly(IBVE), poly(CEVE), and poly ( $n$-BVE) were synthesized in emulsions (using CTAB, SDBS, and $\mathrm{NP}-40$ as cationic, anionic, and non-ionic surfactants, respectively). Only trace amounts of poly(CEVE)s and poly(n-BVE)s were synthesized in the emulsion with SDBS at $20{ }^{\circ} \mathrm{C}$. Compared with the polymerizations implemented in $\mathrm{H}_{2} \mathrm{O}$, polymers with lower monomer conversion and $M_{n}$ were obtained in the emulsion at the same reaction time (Figures 6 and 7). The emulsion polymerization was also not controlled. These observations are different from those of aqueous cationic polymerization using LASC as a catalyst in previous studies [26-29]. In these studies, a compound made of a lanthanide triflate and a surfactant, that is, a LASC catalyst, transferred the polymerization sites from 
the monomer/water surface to the interior of the monomer, resulting in the production of long polymer chains. By contrast, the lower yields were observed during emulsion polymerization, probably because the space steric hindrance of these surfactants on the monomer/water surface placed restrictions on the contact between $\mathrm{B}\left(\mathrm{C}_{6} \mathrm{~F}_{5}\right)_{3} / \mathrm{Et}_{2} \mathrm{O}$ and the monomer [45]. The lower molecular weights were due to the formation of smaller droplets (average $51-59 \mathrm{~nm}$ ) in case of emulsion polymerization. Consequently, the polymerization sites were still on the monomer/water surface. The reaction exotherms decreased, and the preparation times during polymerizations increased in the emulsion processes in comparison with those in the high-purity water (Figure S3). In the emulsion with SDBS as an anionic surfactant, mass anions inhibited the positive charge of the active species on the monomer/water surface [45]. Although NP-40 and CTAB are non-ionic and cationic surfactants, the space steric hindrance still suppressed the monomer conversion.
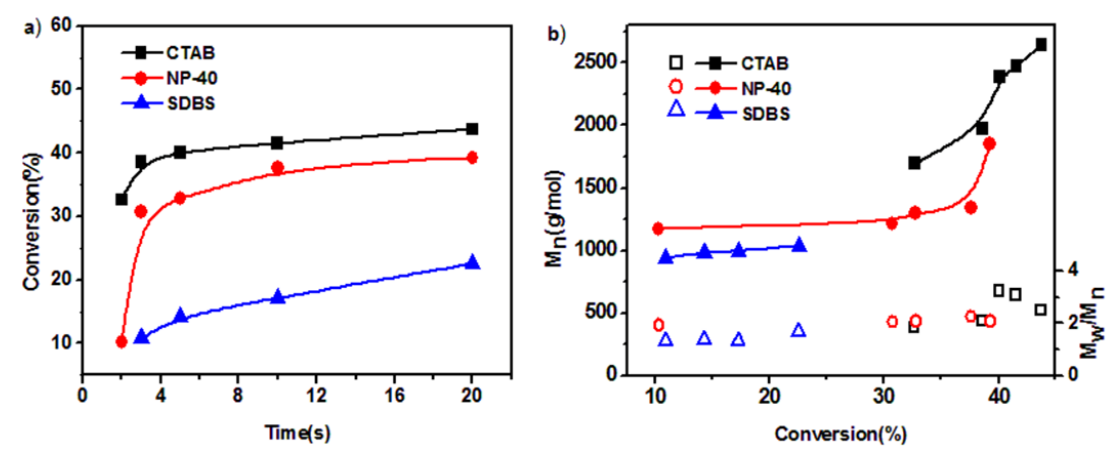

Figure 6. IBVE cationic polymerization initiated by $\mathrm{CumOH} / \mathrm{B}\left(\mathrm{C}_{6} \mathrm{~F}_{5}\right)_{3} / \mathrm{Et}_{2} \mathrm{O}$ in emulsion at $20{ }^{\circ} \mathrm{C}$ : (a) conversion vs. time; (b) $M_{n}$ and $M_{w} / M_{n}$ vs. conversion; [IBVE] $=1.6 \mathrm{M}$; [CumOH] = $\left[\mathrm{B}\left(\mathrm{C}_{6} \mathrm{~F}_{5}\right)_{3}\right]=0.05 \mathrm{M} ;\left[\mathrm{Et}_{2} \mathrm{O}\right]=0.1 \mathrm{M} ; \mathrm{CTAB}=0.02 \mathrm{~g} ; \mathrm{NP}-40=0.02 \mathrm{~g} ; \mathrm{SDBS}=0.02 \mathrm{~g}$.
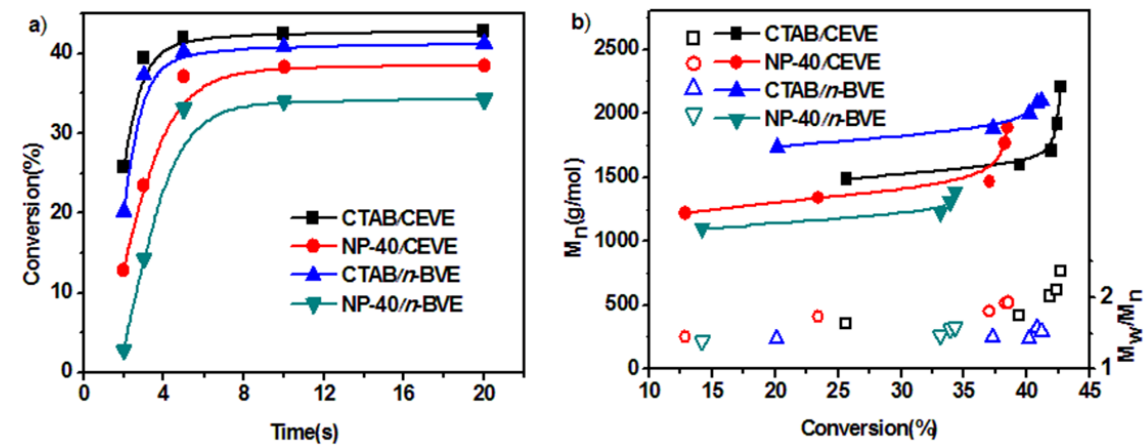

Figure 7. CEVE and $n$-BVE cationic polymerization initiated by $\left.\mathrm{CumOH} / \mathrm{B}_{(} \mathrm{C}_{6} \mathrm{~F}_{5}\right)_{3} / \mathrm{Et}_{2} \mathrm{O}$ in an emulsion at $20{ }^{\circ} \mathrm{C}$ : (a) conversion vs. time; (b) $M_{n}$ and $M_{w} / M_{n}$ vs. conversion; [CEVE] = $2.0 \mathrm{M}$; $[n-\mathrm{BVE}]=1.6 \mathrm{M} ;[\mathrm{CumOH}]=\left[\mathrm{B}\left(\mathrm{C}_{6} \mathrm{~F}_{5}\right)_{3}\right]=0.05 \mathrm{M} ;\left[\mathrm{Et}_{2} \mathrm{O}\right]=0.1 \mathrm{M} ; \mathrm{CTAB}=0.02 \mathrm{~g} ; \mathrm{NP}-40=0.02 \mathrm{~g}$.

\subsection{Polymer Characterization}

The terminal structures of poly(IBVE), poly(CEVE), and poly(n-BVE) obtained in aqueous suspensions and emulsions were examined by ${ }^{1} \mathrm{H}-\mathrm{NMR}$ spectroscopy (Figure 8). The characteristic signals at 0.90 (peak g), 1.60 (peak f), 1.79 (peak c), 3.17 (peak e), and 3.56 (peak d) ppm were assigned to the main chain protons of the monomer unit of poly(IBVE). The characteristic signals at 1.00-2.09 (peak c) and 3.4-4.00 (peaks d, e, s) ppm were assigned to the main chain protons of the monomer unit of poly(CEVE). The characteristic signals at 0.90 (peak g), 1.10-1.75 (peaks c, u, v), and 3.25-4.00 (peaks $\mathrm{d}$, e) ppm were assigned to the main chain protons of the monomer unit of poly ( $n$-BVE). The signals at 1.11 (peak a) and 7.00-7.20 (peak b) ppm were assigned to $-\mathrm{CH}_{3}$ and the phenyl group at the $\alpha$-end (Figure 8), respectively. The signals at 2.52 (peak j), 5.35 (peak i), and 5.60 (peak h) ppm were attributed to the mid-chain (internal) olefin group formed due to chain transfer to the polymer [22]. In 
addition, the following three types of $\omega$-end groups were examined in the ${ }^{1} \mathrm{H}$-NMR spectra (Figure 8): acetal (resonance at $4.73 \mathrm{ppm}$ (peak q)), aldehyde (resonances at 2.49 (peak p), and 9.81 (peak $\mathrm{t}$ ) ppm, respectively) and alkenal (resonances at 6.09 (peak n), 6.90 (peak m), and 9.54 (peak k) ppm, respectively).

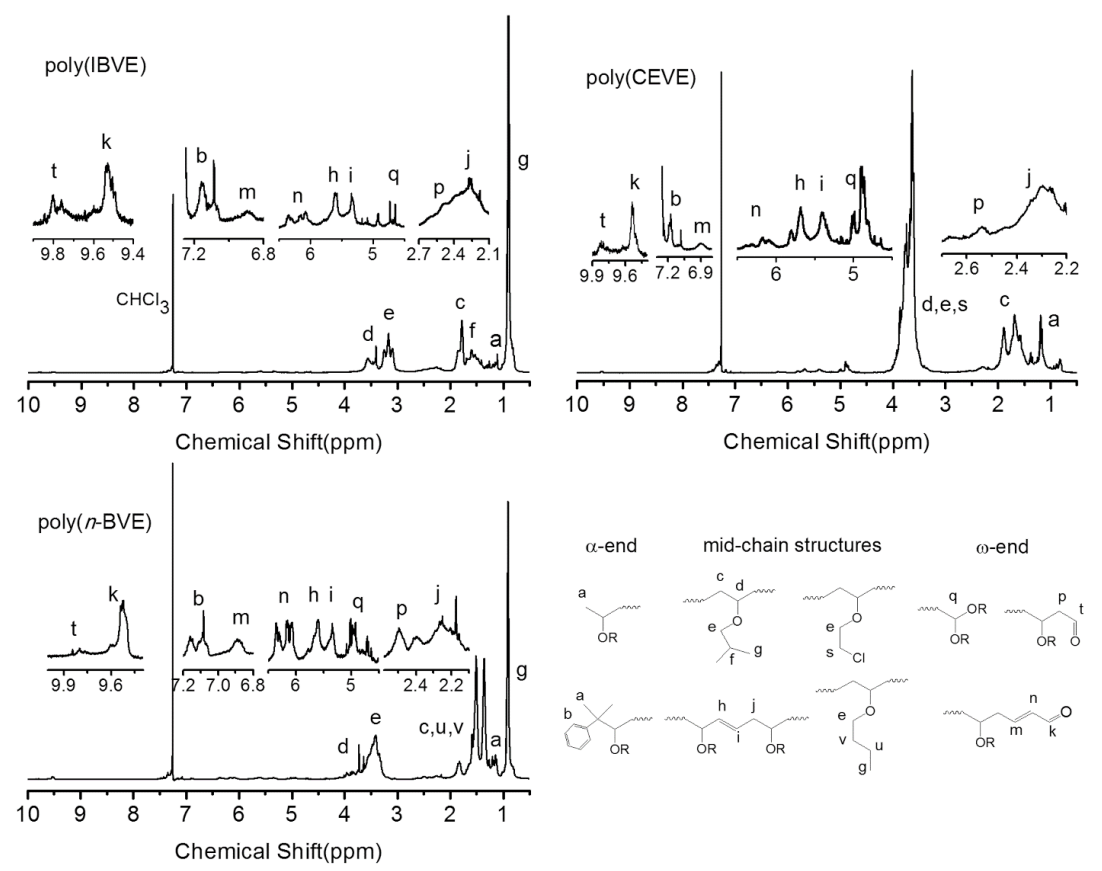

Figure 8. ${ }^{1} \mathrm{H}-\mathrm{NMR}$ spectra of poly(IBVE), poly(CEVE), and poly(n-BVE) initiated by $\mathrm{CumOH} /$ $\mathrm{B}\left(\mathrm{C}_{6} \mathrm{~F}_{5}\right)_{3} / \mathrm{Et}_{2} \mathrm{O}$ in aqueous media.

The content of the $\omega$-end and mid-chain (internal) olefin groups of polymers initiated by $\mathrm{CumOH} / \mathrm{B}\left(\mathrm{C}_{6} \mathrm{~F}_{5}\right)_{3} / \mathrm{Et}_{2} \mathrm{O}$ in aqueous media is presented in Table 3 . For polymerization in the emulsion, the content of mid-chain olefin groups (0.1-0.2 double bonds per polymer chain) was present in minor amounts. $\beta$-H elimination, a typical chain-transfer reaction for conventional cationic polymerization of vinyl ethers $[16,47]$ leading terminal double-bond groups, was not observed in the ${ }^{1} \mathrm{H}-\mathrm{NMR}$ spectra of the polymers synthesized in aqueous media. A possible reason was that these reactive terminal double-bond groups were consumed in chain coupling reactions [37], which is one reason the total content of the $\omega$-end groups was lower than $100 \%$ (Table 3). Another reason is that a small extent of polymerization was initiated by $\mathrm{H}_{2} \mathrm{O} / \mathrm{B}\left(\mathrm{C}_{6} \mathrm{~F}_{5}\right)_{3} / \mathrm{Et}_{2} \mathrm{O}$. The chain coupling reaction led to an overestimation of the phenyl head group content (see Section 3.6 for details).

Table 3. Functionality at the $\omega$-end and mid-chain (internal) olefin group content of polymers initiated by $\mathrm{CumOH} / \mathrm{B}\left(\mathrm{C}_{6} \mathrm{~F}_{5}\right)_{3}$ at $20{ }^{\circ} \mathrm{C}$ in aqueous media. ${ }^{\mathrm{a}}$

\begin{tabular}{|c|c|c|c|c|c|}
\hline Run & Media & Acetal $^{\mathrm{b}}(\%)$ & Aldehyde $^{\mathrm{b}}(\%)$ & Alkenal $^{\mathrm{b}}(\%)$ & Internal Olefin ${ }^{\mathrm{c}}$ (per Chain) \\
\hline 16 & $\mathrm{H}_{2} \mathrm{O}$ & 31.8 & 31.5 & 26.7 & 0.4 \\
\hline 17 & $n$-hexane $/ \mathrm{H}_{2} \mathrm{O}$ & 28.2 & 35.1 & 28.7 & 0.3 \\
\hline 18 & Toluene $/ \mathrm{H}_{2} \mathrm{O}$ & 27.0 & 36.0 & 27.0 & 0.4 \\
\hline 19 & $\mathrm{NaCl}$ solution & 17.0 & 46.1 & 30.0 & 0.5 \\
\hline 20 & CTAB & 27.9 & 39.6 & 23.5 & 0.1 \\
\hline 21 & NP-40 & 28.8 & 33.4 & 27.9 & 0.2 \\
\hline 22 & SDBS & 39.8 & 34.8 & 19.5 & 0.1 \\
\hline $23^{d}$ & $\mathrm{H}_{2} \mathrm{O}$ & 33.8 & 20.6 & 3.2 & 0.4 \\
\hline $24^{\mathrm{e}}$ & $\mathrm{H}_{2} \mathrm{O}$ & 11.7 & 41.6 & 38.6 & 0.8 \\
\hline
\end{tabular}

${ }^{\mathrm{a}}$ IBVE Polymerization conditions, see Table $2 .{ }^{\mathrm{b}}$ Calculated by ${ }^{1} \mathrm{H}-\mathrm{NMR}$ spectroscopy as acetal [5I(q)/I(b)], aldehyde $[5 I(\mathrm{t}) / I(\mathrm{~b})]$, and alkenal $[5 I(\mathrm{k}) / I(\mathrm{~b})] .{ }^{c}$ Calculated as the ratio of integrals (normalized to one hydrogen) as $5 I(\mathrm{i}) / I(\mathrm{~b})$.

${ }^{\mathrm{d}}$ CEVE polymerization, $[\mathrm{CEVE}]=2.0 \mathrm{M}$. ${ }^{\mathrm{e}} n$-BVE polymerization, $[n-\mathrm{BVE}]=1.6 \mathrm{M}$. 


\subsection{Possible Interactions Between the Initiator and Co-initiator}

Given that $\mathrm{H}_{2} \mathrm{O}, \mathrm{EtOH}, \mathrm{IPA}$, and $\mathrm{CumOH}$ could induce the aqueous cationic polymerization of vinyl ethers, DFT was applied to investigate the competition between $\mathrm{H}_{2} \mathrm{O}$ and alcohol combined with $\mathrm{B}\left(\mathrm{C}_{6} \mathrm{~F}_{5}\right)_{3}$ for providing a theoretical basis. Models of active center were built at the 6-31G level, such as $\mathrm{H}^{+}-\mathrm{B}\left(\mathrm{C}_{6} \mathrm{~F}_{5}\right)_{3}-\mathrm{OH}^{-}, \mathrm{CH}_{3} \mathrm{CH}_{2}{ }^{+}-\mathrm{B}\left(\mathrm{C}_{6} \mathrm{~F}_{5}\right)_{3}-\mathrm{OH}^{-},\left(\mathrm{CH}_{3}\right)_{2} \mathrm{CH}^{+}-\mathrm{B}\left(\mathrm{C}_{6} \mathrm{~F}_{5}\right)_{3}-\mathrm{OH}^{-}$, and $\left(\mathrm{CH}_{3}\right)_{2} \mathrm{C}\left(\mathrm{C}_{6} \mathrm{H}_{5}\right)^{+}-\mathrm{B}\left(\mathrm{C}_{6} \mathrm{~F}_{5}\right)_{3}-\mathrm{OH}^{-}$. The strain energy was minimized through structural optimization in bond angles and lengths. The activation energy required to form $\mathrm{H}^{+}-\mathrm{B}\left(\mathrm{C}_{6} \mathrm{~F}_{5}\right)_{3}-\mathrm{OH}^{-}$active center was the most in all these four ion pair models (Figure 9), which indicated that $B\left(C_{6} F_{5}\right)_{3}$ was more readily formed in an active center with alcohols when alcohols were present in the aqueous media. The $\mathrm{C}^{+\cdots} \mathrm{B}$ distance in $\left(\mathrm{CH}_{3}\right)_{2} \mathrm{C}\left(\mathrm{C}_{6} \mathrm{H}_{5}\right)^{+}-\mathrm{B}\left(\mathrm{C}_{6} \mathrm{~F}_{5}\right)_{3}-\mathrm{OH}^{-}(3.99 \AA)$ was the shortest in all the models of active center formed by alcohols and $\mathrm{B}\left(\mathrm{C}_{6} \mathrm{~F}_{5}\right)_{3}$. Furthermore, the models of $\left(\mathrm{CH}_{3}\right)_{2} \mathrm{C}\left(\mathrm{C}_{6} \mathrm{H}_{5}\right)^{+}-\mathrm{B}\left(\mathrm{C}_{6} \mathrm{~F}_{5}\right)_{3}-\mathrm{OH}^{-}$presented a large steric hindrance, indicating that the propagating carbocation with the $\mathrm{CumOH} / \mathrm{B}\left(\mathrm{C}_{6} \mathrm{~F}_{5}\right)_{3}$ initiating system was much more sterically hindered, such that more restriction occurred in the direction of the insertion of monomer molecules into the propagating carbocation. Therefore, the polymerization initiated by $\mathrm{CumOH} / \mathrm{B}\left(\mathrm{C}_{6} \mathrm{~F}_{5}\right)_{3}$ was stable.
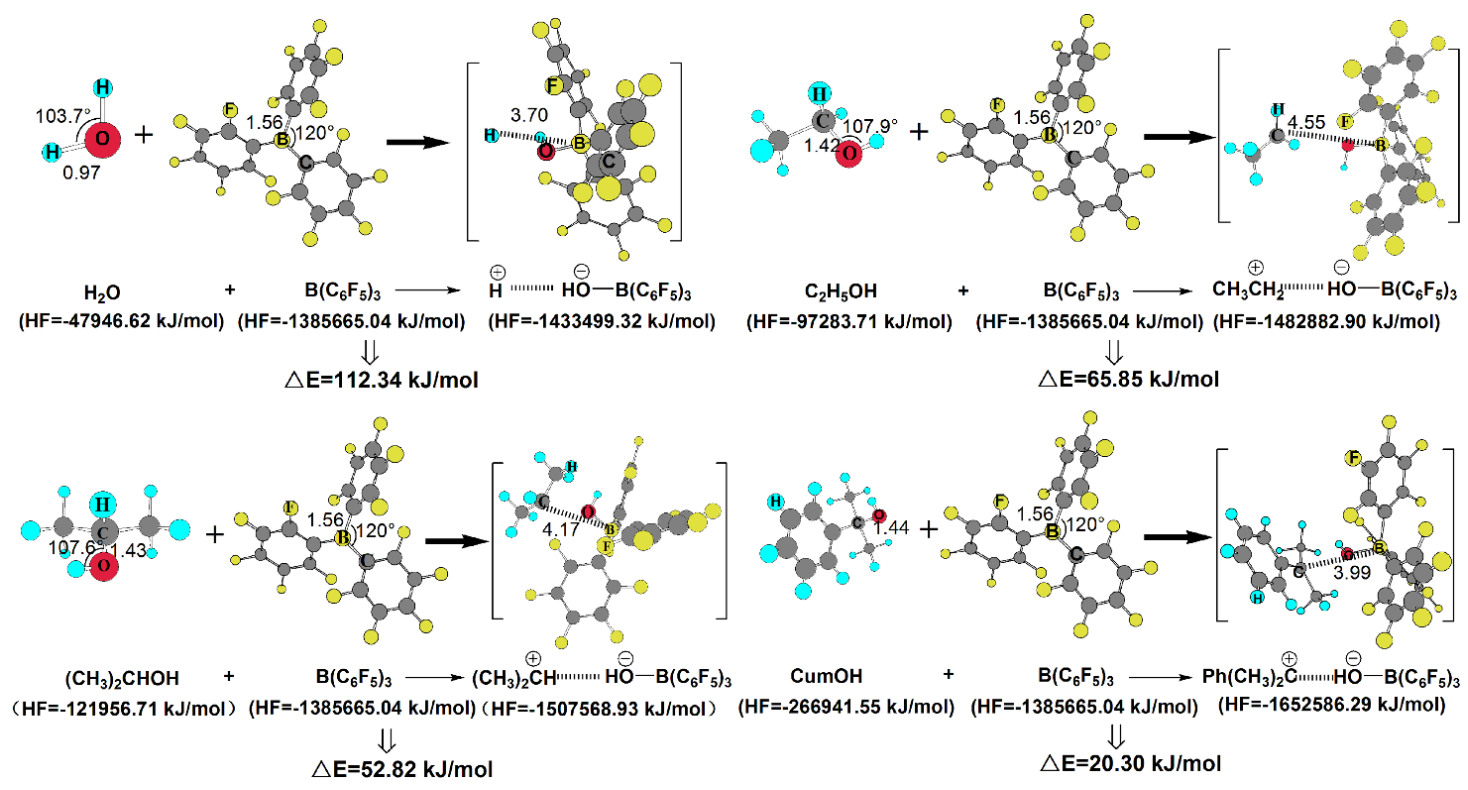

Figure 9. The optimized conformations of $\mathrm{H}^{+}-\mathrm{B}\left(\mathrm{C}_{6} \mathrm{~F}_{5}\right)_{3}-\mathrm{OH}^{-}, \mathrm{CH}_{3} \mathrm{CH}_{2}{ }^{+}-\mathrm{B}\left(\mathrm{C}_{6} \mathrm{~F}_{5}\right)_{3}-\mathrm{OH}^{-}$, $\left(\mathrm{CH}_{3}\right)_{2} \mathrm{CH}^{+}-\mathrm{B}\left(\mathrm{C}_{6} \mathrm{~F}_{5}\right)_{3}-\mathrm{OH}^{-}$and $\left(\mathrm{CH}_{3}\right)_{2} \mathrm{C}\left(\mathrm{C}_{6} \mathrm{H}_{5}\right)^{+}-\mathrm{B}\left(\mathrm{C}_{6} \mathrm{~F}_{5}\right)_{3}-\mathrm{OH}^{-}$at the 6-31 $\mathrm{G}^{*}$ level.

\subsection{Proposed Mechanism for Polymerization}

The polymerization (initiation, propagation, and termination) sites were on the monomer/water surface for the aqueous cationic polymerization of vinyl ether initiated by $\mathrm{B}\left(\mathrm{C}_{6} \mathrm{~F}_{5}\right)_{3} / \mathrm{Et}_{2} \mathrm{O}$, similar to the aqueous cationic polymerization of styrene derivatives $[45,48,49]$. However, the polymerization processes shared three special features in comparison with the cationic polymerization of other monomers initiated by other co-initiators. The first feature was the severely exothermic nature and poor reproducibility of vinyl ether polymerization due to the high reactivity of this monomer. To overcome this disadvantage, different initiators, co-solvents ( $n$-hexane and toluene), $\mathrm{NaCl}$ solutions, and surfactants were added to the experiments. $\mathrm{CumOH} / \mathrm{B}\left(\mathrm{C}_{6} \mathrm{~F}_{5}\right)_{3} / \mathrm{Et}_{2} \mathrm{O}$ induced polymerization in a reproducible manner in the suspension and emulsion. The second feature was about the decrease in monomer conversion and $M_{n}$ when the reaction temperature was reduced using $B\left(C_{6} F_{5}\right)_{3}$ as a co-initiator; this process was contrary to traditional cationic polymerizations $[1-3,46]$. The third feature was that low yields and $M_{n}$ were obtained in $n$-hexane $/ \mathrm{H}_{2} \mathrm{O}$, toluene $/ \mathrm{H}_{2} \mathrm{O}, \mathrm{NaCl}$ solution, and 
emulsion in comparison with high-purity water; this process was opposite to the aqueous cationic polymerizations using other co-initiators [26-28,37].

According to the experimental data, a mechanism for the aqueous cationic polymerization of vinyl ether was proposed (Scheme 1). In the initiation, $\mathrm{B}\left(\mathrm{C}_{6} \mathrm{~F}_{5}\right)_{3} / \mathrm{Et}_{2} \mathrm{O}$ captured a hydroxyl group from $\mathrm{CumOH}$ to form the $\left(\mathrm{CH}_{3}\right)_{2} \mathrm{C}\left(\mathrm{C}_{6} \mathrm{H}_{5}\right)^{+}-\mathrm{Et}_{2} \mathrm{OB}\left(\mathrm{C}_{6} \mathrm{~F}_{5}\right)_{3}-\mathrm{OH}^{-}$active center (structure A). The structure $\mathrm{A}$ then initiated the polymerization, and the propagation was extremely fast until chain-transfer reactions or termination occurred. The chain-transfers via $\beta$-H elimination formed a terminal double-bond group that was highly reactive $[37,50]$. This terminal olefin group readily reacted with structure $A$, thereby forming coupled chains that resulted in polymers with two head groups (structure B) [35,51]. The chain-transfers by the monomer generated an acetal end group (structure C) [22]. The chain-transfers by water generated an hydroxyl end group (structure D), but the low stability of hemiacetal for poly(vinyl ether)s led to hydroxyl end group (structure D) conversion into an aldehyde end group (structure E) or acetal end group (structure C). The aldehyde end group lost $\mathrm{ROH}$ to form an alkenal end group (structure F) [37]. In addition, only trace amounts (Table 3) of mid-chain olefin groups (structure G) were detected in the aqueous polymerization due to chain-transfer to the polymer [35], which was a typical side reaction in the conventional cationic polymerization of vinyl ethers.

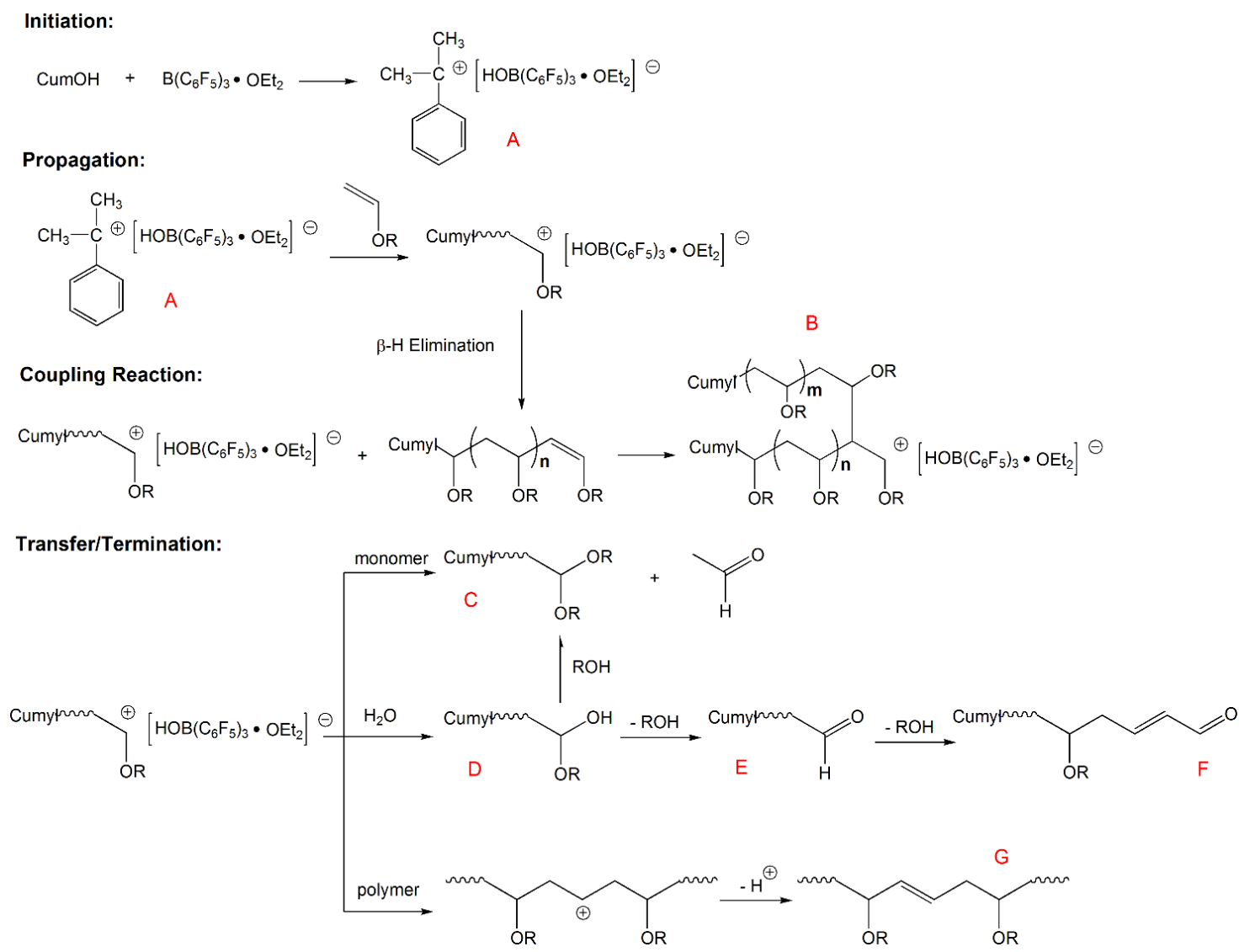

Scheme 1. Proposed mechanism for the aqueous cationic polymerization of vinyl ethers using $\mathrm{CumOH} / \mathrm{B}\left(\mathrm{C}_{6} \mathrm{~F}_{5}\right)_{3} / \mathrm{Et}_{2} \mathrm{O}$.

\section{Conclusions}

Poly(IBVE)s, poly(CEVE)s, and poly(n-BVE)s were successfully achieved in aqueous suspensions and emulsions using $\mathrm{B}\left(\mathrm{C}_{6} \mathrm{~F}_{5}\right)_{3} / \mathrm{Et}_{2} \mathrm{O}$ as a co-initiator and alcohols as an initiator in a reproducible manner. Polymerization characteristics were systematically tested and compared in the suspension and emulsion. Adding co-solvents ( $n$-hexane and toluene), $\mathrm{NaCl}$, and surfactants could transfer heat effectively in the reaction. However, low yields and molecular weights were obtained in comparison 
with high-purity water. The polymerization rate surprisingly decreased when the temperature was lowered; this result was opposite to that in traditional cationic polymerizations. The aqueous cationic polymerization sites were located on the monomer/water surface. The end group structures of polymers examined by ${ }^{1} \mathrm{H}-\mathrm{NMR}$ spectroscopy indicated that various chain-transfer reactions (to monomers, water, and polymers) occurred in these processes. Accordingly, the mechanism for the aqueous cationic polymerization of vinyl ethers using $\mathrm{CumOH} / \mathrm{B}\left(\mathrm{C}_{6} \mathrm{~F}_{5}\right)_{3} / \mathrm{Et}_{2} \mathrm{O}$ was proposed.

Supplementary Materials: The following are available online at http:/ / www.mdpi.com/2073-4360/11/3/500/s1, Figure S1: Suspension polymerization of styrene at $20{ }^{\circ} \mathrm{C}$ : (a) conversion vs time; (b) $\ln \left[\mathrm{M}_{0}\right] /[\mathrm{M}]$ vs time.

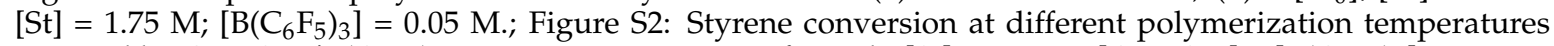
initiated by CumOH $/ \mathrm{B}\left(\mathrm{C}_{6} \mathrm{~F}_{5}\right)_{3}$ in aqueous suspension for $50 \mathrm{~h}$. $[\mathrm{St}]=1.75 \mathrm{M}$; $[\mathrm{CumOH}]=\left[\mathrm{B}\left(\mathrm{C}_{6} \mathrm{~F}_{5}\right)_{3}\right]=0.05 \mathrm{M}$; $\mathrm{NaCl}: 1 \mathrm{~g}$;; and Figure S3: Temperature during cationic polymerizations initiated by $\mathrm{CumOH} / \mathrm{B}\left(\mathrm{C}_{6} \mathrm{~F}_{5}\right)_{3}$ in aqueous emulsion at $20^{\circ} \mathrm{C}$. $[\mathrm{IBVE}]=1.6 \mathrm{M} ;[\mathrm{CEVE}]=2.0 \mathrm{M} ;[\mathrm{n}-\mathrm{BVE}]=1.6 \mathrm{M} ;[\mathrm{CumOH}]=\left[\mathrm{B}\left(\mathrm{C}_{6} \mathrm{~F}_{5}\right)_{3}\right]=0.05 \mathrm{M} ; \mathrm{CTAB}=0.02$ g; NP-40 $=0.02 \mathrm{~g}$; SDBS $=0.02 \mathrm{~g}$.

Author Contributions: J.Z. and Y.W. conceived and designed the experiments; J.Z. and K.C. performed the experiments; J.Z. and Y.W. analyzed the data; Y.W., S.L. and W.G. contributed resources and supervision; M.Z. and D.Y. contributed methodology; L.G. contributed molecular calculations; J.Z. wrote the paper.

Funding: This research was funded by the National Natural Science Foundation of China (No.51573020), Beijing Natural Science Foundation (No. 2172022), Scientific Research Project of Beijing Educational Committee (KM201810017008), Project of Petrochina (No. PRIKY17041), and URT Program (No. 2018J00029).

Conflicts of Interest: The authors declare no conflicts of interest.

\section{References}

1. Rajasekhar, T.; Emert, J.; Wolf, L.M.; Faust, R. Controlled catalytic chain transfer polymerization of isobutylene in the presence of tert-butanol as exp-enhancer. Macromolecules 2018, 51, 3041-3049. [CrossRef]

2. Hadjikyriacou, S.; Faust, R. Amphiphilic block copolymers by sequential living cationic polymerization: Synthesis and characterization of poly(isobutylene-b-methyl vinyl ether). Macromolecules 1996, 29, 5261-5267. [CrossRef]

3. Kanazawa, A.; Kanaoka, S.; Aoshima, S. Living cationic polymerization of vinyl ether with methanol/metal chloride initiating system: Relationship between polymerization behavior and the nature of Lewis acids. Macromolecules 2010, 43, 2739-2747. [CrossRef]

4. Kanazawa, A.; Kanaoka, S.; Aoshima, S. Heterogeneously catalyzed living cationic polymerization of isobutyl vinyl ether using iron(III) oxode. J. Am. Chem. Soc. 2007, 129, 2420-2421. [CrossRef] [PubMed]

5. Aoshima, S.; Kanaoka, S. A renaissance in living cationic polymerization. Chem. Rev. 2009, 109, 5245-5287. [CrossRef]

6. De, P.; Faust, R. Living carbocationic polymerization of p-methoxystyrene using p- methoxystyrene hydrochloride/SnBr4 initiating system: Determination of the absolute rate constant of propagation for ion pairs. Macromolecules 2004, 37, 7930-7937. [CrossRef]

7. Wu, Y.; Ren, P.; Guo, W.; Li, S.; Yang, X.; Shang, Y. Living cationic sequential block copolymerization: Synthesis and characterization of poly(4-(2-hydroxyethyl)styrene- $b$-isobutylene- $b$-4-(2-hydroxyethyl) styrene)triblock copolymers. Polym. J. 2010, 42, 268-272. [CrossRef]

8. Zhang, L.; Wu, Y.; Li, S.; Mao, J.; Guo, W.; Chang, J.; Zhang, T.; Wu, S. Synthesis of branched butyl rubber with bimodal distribution by cationic polymerization and its structures and properties. Acta Polym. Sin. 2015, 9, 1028-1035.

9. Anastas, P.T.; Kirchhoff, M.M. Origins, current status, and future challenges of green chemistry. Acc. Chem. Res. 2002, 35, 686-694. [CrossRef]

10. Horváth, I.T.; Anastas, P.T. Innovations and green chemistry. Chem. Rev. 2007, 107, 2169-2173. [CrossRef]

11. Kostjuk, S.V.; Vasilenko, I.V.; Shiman, D.I.; Frolov, A.N.; Gaponik, L.V. Highly reactive polyisobutylenes via cationic polymerization of isobutylene by $\mathrm{AlCl}_{3} /$ Ether complexes in non-polar media: Scope and limitations. Macromol. Symp. 2015, 349, 94-103. [CrossRef]

12. Vasilenko, I.V.; Shiman, D.I.; Kostjuk, S.V. Highly reactive polyisobutylenes via $\mathrm{AlCl}_{3} \mathrm{OBu}_{2}$-coinitiated cationic polymerization of isobutylene: Effect of solvent polarity, temperature, and initiator. J. Polym. Sci. Part A Polym. Chem. 2012, 50, 750-758. [CrossRef] 
13. Xie, Y.; Chang, J.; Wu, Y.; Yang, D.; Wang, H.; Zhang, T.; Li, S.; Guo, W. Synthesis and properties of bromide-functionalized poly(isobutylene-co- $p$-methylstyrene) random copolymer. Polym. Int. 2017, 66, 468-476. [CrossRef]

14. Mingotaud, A.F.; Cansell, F.; Gilbert, N.; Soum, A. Cationic and anionic ring-opening polymerization in supercritical $\mathrm{CO}_{2}$ preliminary results. Polym. J. 1999, 153, 77-86. [CrossRef]

15. Clark, M.R.; Desimone, J.M. Cationic polymerization of vinyl and cyclic ethers in supercritical and liquid carbon dioxide. Macromolecules 1995, 28, 3002-3004. [CrossRef]

16. Wu, Y.; Han, L.; Zhang, X.; Mao, J.; Gong, L.; Guo, W.; Gi, K.; Li, S. Cationic polymerization of isobutyl vinyl ether in an imidazole-based ionic liquid: Characteristics and mechanism. Polym. Chem. 2015, 6, 2560-2568. [CrossRef]

17. Zhang, X.; Guo, W.; Wu, Y.; Gong, L.; Li, W.; Li, X.; Li, S.; Shang, Y.; Yang, D.; Wang, H. Cationic polymerization of $p$-methylstyrene in selected ionic liquids and polymerization mechanism. Polym. Chem. 2016, 7, 5099-5112. [CrossRef]

18. Zhang, X.; Guo, W.; Wu, Y.; Li, W.; Li, S.; Shang, Y.; Zhang, J. Solubility of monomers for chain polymerization in ionic liquids predicted by the conductor-like screening model for real solvents. Ind. Eng. Chem. Res. 2017, 56, 14694-14703. [CrossRef]

19. Han, L.; Wu, Y.; Dan, Y.; Wang, H.; Zhang, X.; Wei, X.; Guo, W.; Li, S. Characteristics and mechanism of styrene cationic polymerization in 1-butyl-3-methylimidazolium hexafluorophosphate ionic liquid. RSC Adv. 2016, 6, 105322-105330. [CrossRef]

20. Zhang, X.; Guo, W.; Wu, Y.; Shang, Y.; Li, S.; Xiong, W. Synthesis of random copolymer of isobutylene with p-methylstyrene by cationic polymerization in ionic liquids. E-polymers 2018, 18, 423-431. [CrossRef]

21. Kostjuk, S.V.; Ganachaud, F. Cationic polymerization of vinyl monomers in aqueous media: From monofunctional oligomers to long-lived polymer chains. Acc. Chem. Res. 2010, 43, 357-367. [CrossRef] [PubMed]

22. Huang, Q.; Wu, Y.; Dan, J. Cationic polymerization of isobutyl vinyl ether coinitiated with heteropolyacid or its salts in aqueous medium. J. Polym. Sci. Part A Polym. Chem. 2013, 51, 546-556. [CrossRef]

23. Satoh, K.; Kamigaito, A.M.; Sawamoto, M. Controlled cationic polymerization of $p$-methoxystyrene in aqueous media with $\mathrm{Yb}(\mathrm{OTf})_{3}$. Macromolecules 1999, 32, 3827-3832. [CrossRef]

24. Satoh, K.; Kamigaito, A.M.; Sawamoto, M. Direct living cationic polymerization of $p$-hydroxystyrene with boron trifluoride etherate in the presence of water. Macromolecules 2000, 33, 5405-5410. [CrossRef]

25. Satoh, K.; Kamigaito, A.M.; Sawamoto, M. Metal triflates and tetrafluoroborates as water-tolerant Lewis Acids for cationic polymerization in aqueous media. Macromolecules 2000, 33, 5836-5840. [CrossRef]

26. Touchard, V.; Graillat, C.; Boisson, C.; D'Agosto, A.F.; Spitz, R. Use of a Lewis Acid surfactant combined catalyst in cationic polymerization in miniemulsion apparent and hidden initiators. Macromolecules 2004, 37, 3136-3142. [CrossRef]

27. Vasilenko, I.V.; Yeong, H.Y.; Delgado, M.; Ouardad, S.; Peruch, F.; Voit, B.; Ganachaud, F.; Kostjuk, S.V. A catalyst platform for unique cationic (co)polymerizationin aqueous emulsion. Angew. Chem. Int. Ed. 2015, 54, 12728-12732. [CrossRef]

28. Vasilenko, I.V.; Ganachaud, F.; Kostjuk, S.V. New insights into the cationic polymerization in emulsion catalyzed by water-dispersible Lewis Acid surfactant complexes: A case study with p-methoxystyrene. Macromolecules 2016, 49, 3264-3273. [CrossRef]

29. Cauvin, S.; Ganachaud, F.; Moreau, M.; Hémery, P. High molar mass polymers by cationic polymerisation in emulsion and miniemulsion. Chem. Commun. 2005, 21, 2713-2715. [CrossRef]

30. Satoh, K.; Nakashima, J.; Kamigaito, M.; Sawamoto, M. Novel BF $\mathrm{OEt}_{2} / \mathrm{R}-\mathrm{OH}$ initiating system for controlled cationic polymerization of styrene in the presence of water. Macromolecules 2001, 34, 396-401. [CrossRef]

31. Radchenko, A.V.; Kostjuk, S.V.; Vasilenko, I.V.; Ganachaud, F.; Kaputsky, F.N. Controlled/living cationic polymerization of styrene with BF3OEt2 as a coinitiator in the presence of water: Improvements and limitations. Eur. Polym. J. 2007, 43, 2576-2583. [CrossRef]

32. Kostjuk, S.V.; Ganachaud, F. Cationic polymerization of styrene in solution and aqueous suspension using $\mathrm{B}\left(\mathrm{C}_{6} \mathrm{~F}_{5}\right)_{3}$ as a water-tolerant Lewis Acid. Macromolecules 2006, 39, 3110-3113. [CrossRef]

33. Kostjuk, S.V.; Ganachaud, F.; Radchenko, A.V.; Vasilenko, I.V. Cationic polymerization of styrene derivatives and cyclopentadiene catalyzed by $\mathrm{B}\left(\mathrm{C}_{6} \mathrm{~F}_{5}\right)_{3}$ in aqueous media: Comparison of suspension, emulsion and dispersion processes. Macromol. Symp. 2011, 308, 1-7. [CrossRef] 
34. Kostjuk, S.V.; Radchenko, A.V.; Ganachaud, F. Controlled cationic polymerization of cyclopentadiene with $\mathrm{B}\left(\mathrm{C}_{6} \mathrm{~F}_{5}\right)_{3}$ as a coinitiator in the presence of water. J. Polym. Sci. Part A Polym. Chem. 2008, 46, 4734-4747. [CrossRef]

35. Kostjuk, S.V.; Ouardad, S.; Peruch, F.; Deffieux, A.; Absalon, C.; Puskas, J.E.; Ganachaud, F. Carbocationic polymerization of isoprene co-initiated by $\mathrm{B}\left(\mathrm{C}_{6} \mathrm{~F}_{5}\right)_{3}$ : An alternative route toward natural rubber polymer analogues? Macromolecules 2011, 44, 1372-1384. [CrossRef]

36. Mathers, R.T.; Lewis, S.P. Aqueous cationic olefin polymerization using tris(pentafluorophenyl)gallium and aluminum. J. Polym. Sci. Part A Polym. Chem. 2012, 50, 1325-1332. [CrossRef]

37. Radchenko, A.V.; Kostjuk, S.V.; Ganachaud, F. Cationic polymerization of isobutyl vinyl ether in aqueous media: Physical chemistry tricks to fight against thermal runaway. Polym. Chem. 2013, 4, 1883-1892. [CrossRef]

38. Lewis, S.P.; Henderson, L.D.; Chandler, B.D.; Parvez, M.; Piers, W.E.; Collins, S. Aqueous suspension polymerization of isobutene initiated by 1,2- $\mathrm{C}_{6} \mathrm{~F}_{4}\left[\mathrm{~B}\left(\mathrm{C}_{6} \mathrm{~F}_{5}\right)_{2}\right]_{2}$. J. Am. Chem. Soc. 2005, 127, 46-47. [CrossRef]

39. Lewis, S.P.; Chai, J.; Collins, S. Isobutene polymerization using chelating diboranes: Polymerization in aqueous suspension and hydrocarbon solution. Organometallics 2009, 28, 249-263. [CrossRef]

40. Becke, A.D. Density-functional exchange-energy approximation with correct asymptotic behavior. Phys. Rev. A At. Mol. Opt. Phys. 1988, 38, 3098-3100. [CrossRef]

41. Perdew, J.P. Density-functional approximation for the correlation energy of the inhomogeneous electron gas. Phys. Rev. B Condens. Matter 1986, 33, 8822-8824. [CrossRef] [PubMed]

42. Kumar, R.; Dimitrov, P.; Bartelson, K.J.; Emert, J.; Faust, R. Polymerization of isobutylene by $\mathrm{GaCl}_{3}$ or $\mathrm{FeCl}_{3}$ /ether complexes in nonpolar solvents. Macromolecules 2012, 45, 8598-8603. [CrossRef]

43. Liu, Q.; Wu, Y.; Yan, P.; Zhang, Y.; Xu, R. Polyisobutylene with high exo-olefin content via $\beta$-H elimination in the cationic polymerization of isobutylene with $\mathrm{H}_{2} \mathrm{O} / \mathrm{FeCl}_{3}$ /dialkyl ether initiating system. Macromolecules 2011, 44, 1866-1875. [CrossRef]

44. Zhu, S.; Wang, K.; Lu, Y. Effects of ether on the cationic polymerization of isobutylene catalyzed by $\mathrm{AlCl}_{3}$. ACS Omega 2018, 3, 2033-2039. [CrossRef]

45. Zhang, J.; Wu, Y.; Li, X.; Yang, D.; Zhang, M.; Wang, H.; Shang, Y.; Ren, P.; Mu, X.; Li, S.; et al. Characteristics and mechanism of styrene cationic polymerization in aqueous media initiated by cumyl alcohol/B $\left(\mathrm{C}_{6} \mathrm{~F}_{5}\right)_{3}$. Macromol. Chem. Phys. 2019, 220. [CrossRef]

46. Sipos, L.; De, P.; Faust, R. Effect of temperature, solvent polarity, and nature of Lewis Acid on the rate constants in the carbocationic polymerization of isobutylene. Macromolecules 2003, 36, 8282-8290. [CrossRef]

47. Sawamoto, M. Modern cationic vinyl polymerization. Prog. Polym. Sci. 1991, 16, 111-172. [CrossRef]

48. Kostjuk, S.V.; Radchenko, A.V.; Ganachaud, F. Controlled living cationic polymerization of $p$-methoxystyrene in solution and aqueous dispersion using tris(pentafluorophenyl)borane as a Lewis Acid acetonitrile does the Job. Macromolecules 2007, 40, 482-490. [CrossRef]

49. Fuji, Y.; Ando, T.; Kamigaito, M.; Sawamoto, M. Iron-catalyzed suspension living radical polymerizations of acrylates and styrene in water. Macromolecules 2002, 35, 2949-2954. [CrossRef]

50. Vasilenko, I.V.; Frolov, A.N.; Kostjul, S.V. Cationic polymerization of isobutylene using $\mathrm{AlCl}_{3} \mathrm{OBu}_{2}$ as a coinitiator: Synthesis of highly reactive polyisobutylene. Macromolecules 2010, 43, 5503-5507. [CrossRef]

51. Ouardad, S.; Deffieux, A.; Peruch, F. Polyisoprene synthesized via cationic polymerization: State of the art. Pure Appl. Chem. 2012, 84, 2065-2080. [CrossRef]

(C) 2019 by the authors. Licensee MDPI, Basel, Switzerland. This article is an open access article distributed under the terms and conditions of the Creative Commons Attribution (CC BY) license (http://creativecommons.org/licenses/by/4.0/). 